\title{
EFFECT OF BODY SIZE, TEMPERATURE AND STARVATION ON OXYGEN CONSUMPTION OF ANTARCTIC KRILL Euphausia superba
}

\author{
Phan Van Ngan'; Vicente Gomes ${ }^{1}$; Paulo S. M. Carvalho² \& Maria José de A. C. R. Passos' \\ ${ }^{1}$ Instituto Oceanográfico da Universidade de São Paulo \\ (Caixa Postal 66149, 05315-970 São Paulo, SP, Brasil) \\ ${ }^{2}$ Companhia de Tecnologia de Saneamento Ambiental - CETESB \\ (Av. Prof. Frederico Hermann Jr., 345 - 05489-900 São Paulo, SP, Brasil)
}

- Abstract: Routine oxygen consumption of krill was investigated as a general measure of its metabolism and assesses the effects of body size, temperature and starvation on the metabolism. No significant difference in whole animal consumption was detected after 1, 3, 5 and 7 days of starvation. The response of metabolism of krill to temperature shows a zone of independence, from 0 to $1^{\circ} \mathrm{C}$ in which the temperature exerts no effect on metabolism. From 1 to $4^{\circ} \mathrm{C}$ the metabolism increases rapidly in function of temperature. There was a general increase in oxygen consumption with increasing body wet weight. The equation between consumption and wet weight is given by Log $\mathrm{Q}_{02}$ $=2.061+0.987 \times \log W$, with $r=0.86$. The slope of the regression line $b=0.987$ is less than unity, indicating that oxygen consumption per unit weight is greater for the smaller than for the larger krill. Average metabolic rate at $0^{\circ} \mathrm{C}$ of $164 \mathrm{krill}$ is $733.24 \mu \mathrm{O}_{2} \mathrm{~g}(\text { dry wt })^{-1} \mathrm{~h}^{-1}$. The metabolic rate is of $1129.67 \mu \mathrm{IO}_{2} \mathrm{~g}(\text { dry wt })^{-1} \mathrm{~h}^{-1}$ for small krill (13-19 mg dry weight) and $636.16 \mu \mathrm{O}_{2} \mathrm{~g}(\text { dry wt })^{-1} \mathrm{~h}^{-1}$ for larger animals (160-169 mg dry weight). The metabolism of krill is shown to be related to period of adaptation and types of respirometer. Prolonged adaptation period showed adverse effect on metabolism and average oxygen consumption is almost three times higher in respirometers with stirring device than in simple sealed chambers.

- Resumo: O consumo de oxigênio de rotina de krill foi avaliado como uma forma de mensurar seu metabolismo e determinar os efeitos do tamanho, da temperatura e do jejum sobre o mesmo. Não foram detectadas diferenças significativas no consumo total do animal após 1, 3, 5 e 7 dias de jejum. As respostas do metabolismo de krill em função da variação da temperatura demonstraram a existência de uma faixa de independência, de $0^{\circ} \mathrm{C}$ a $1^{\circ} \mathrm{C}$, na qual a temperatura não exerce nenhum efeito sobre o metabolismo. De $1^{\circ} \mathrm{C}$ a $4^{\circ} \mathrm{C}$ o metabolismo aumenta rapidamente em função da temperatura. Houve um aumento significativo no consumo de oxigênio em função do peso. A equação que relaciona o consumo com o peso úmido é dada pela fórmula $\log \mathrm{Q}_{\mathrm{O} 2}=2,061+0,987 \mathrm{x} \operatorname{LogW}$, com $r=0,86$. A declividade da regressão foi menor que a unidade $(b=0.987)$, indicando que o consumo de oxigênio por unidade de peso é maior em animais menores. A média da taxa metabólica de $164 \mathrm{krill}$ a $0^{\circ} \mathrm{C}$ é $733,24 \mu \mathrm{IO}_{2} \mathrm{~g}$ (peso seco) ${ }^{-1} \mathrm{~h}^{-1}$. A taxa metabólica é de $1129,67 \mu \mathrm{lO}_{2} \mathrm{~g}$ (peso seco) ${ }^{-1}$ $\mathrm{h}^{-1}$ para animais pequenos (13 a $19 \mathrm{mg}$ de peso seco) e $636,16 \mu \mathrm{IO}_{2} \mathrm{~g}$ (peso seco) $)^{-1} \mathrm{~h}^{-1}$, para animais maiores (160 a $169 \mathrm{mg}$ de peso seco). Demonstrou-se que o metabolismo do krill está relacionado ao período de adaptação e ao tipo de respirômetro. Períodos prolongados de adaptação ocasionaram efeitos adversos sobre o metabolismo. A média do consumo de oxigênio foi cerca de 3 vezes mais elevada em respirômetros com agitador do que em câmaras seladas simples.

- Descriptors: Oxygen consumption, Krill, Metabolism, Antarctica, Euphausia superba, Temperature, Starvation.

- Descritores: Consumo de oxigênio, Krill, Metabolismo, Antártica, Euphausia superba, Temperatura, Jejum. 


\section{Introduction}

The Antarctic krill, Euphausia superba, is one of the five Euphausiacea species occurring in the Southern Ocean. It is the most abundant single species in the ecosystem and is known to form an important link between primary producers (phytoplankton) and higher consumers (fishes, squids, birds, seals and baleen whales). With enormous biomass (see Miller \& Hampton, 1989 for review), krill may also contribute substantially to the detritus of the ocean because they molt frequently and regularly throughout their life. Due to the trophic importance of krill in the ecosystem a study of its metabolic activity, its basic energy requirements, will contribute to the understanding of energy flow through the food chains. In aerobic organisms the metabolic rate is ordinarily measured in terms of oxygen consumption. Although anaerobic metabolism has not been examined in krill, importance of its contribution to total metabolism seems unlikely since they are organisms living in an oxygen-rich environment. Fry (1971) distinguished three levels of oxygen consumption: standard or resting, routine, and active. Standard oxygen consumption may be taken as oxygen uptake in the absence of spontaneous activity, whereas routine oxygen consumption is the mean oxygen uptake of krill whose only activity is spontaneous. Routine oxygen consumption is of interest since it reflects the normal level of spontaneous movement. Data on oxygen consumption of krill were reviewed by Clark \& Morris (1983), Miller \& Hampton (1989) and Opalinski (1991). These data are generally low but highly variable. Differences in the methods of sampling, maintenance and subsequent handling in the laboratory may all contribute to variability of results between different workers. McWhinnie \& Marciniak (1964) and Ikeda \& Mitchell (1982a) found that the oxygen consumption of krill decreased with holding period in the laboratory.

As a part of a study on energy budgets and the ecological importance of krill in the coastal ecosystem, this work investigates the routine oxygen consumption of krill as a general measure of its metabolism and assesses the effects of body size, temperature, starvation and handlings on the metabolism.

\section{Material and methods}

\section{Sampling}

Specimens of krill, Euphausia superba, were collected in Summer, from January to March, in front of Brazilian Antarctic Station "Comandante
Ferraz" ( $\left.62^{\circ} 05^{\prime} \mathrm{S}, 58^{\circ} 23.5^{\prime} \mathrm{W}\right)$ in Admiralty Bay, King George Island. The animals were caught one by one, using an aquarium hand-net, after being attracted by artificial light to near shore at night. They were kept in aquarium with running sea water, pumped from the bay, for at least two days before being submitted to experiments.

\section{Respirometers}

In order to study the effect of types of respirometer on oxygen consumption two different types of sealed respirometer, one with stirring device and the other static, were used. Basically the respirometer with stirring device was constructed of cylindrical plastic tubing and consists of two chambers, one is animal chamber and the other is stirring chamber. The two chambers were connected one to another by a small tube which was divided longitudinally into two passages to facilitate the circulation of water generated by a small magnetic stirrer mounted in the stirring chamber. The water circulation was used to fan the animal and to bath an oxygen electrode mounted in the stirring chamber continuously with water from the animal chamber. Volume of the system varied from 145 to $160 \mathrm{ml}$. Variation of oxygen concentration due to animal consumption was continuously traced on recorder. Oxygen concentration of water before and after the experiment was cross checked by Winkler titration (Fox \& Wingfield, 1938).

Static respirometers were plastic tubes sealed at one end and screw-capped at the other. Two holes, one large and one small, were made on its wall. The large one $(15 \mathrm{~mm}$ in diameter) was used to introduce krill into the respirometer and to supply running water during adaptation. The small one $(1 \mathrm{~mm}$ in diameter) was used to allow excess water to escape when the large hole was closed and to facilitate the sealing of the system. Volume of the respirometer varies from 113 to 123 cubic centimeters. For both type of respirometer the volume of water used for calculation of consumption was taken as the volume of the respirometer minus the volume of krill which is estimated by dividing the body weight in gram to 1.070 , density of adult krill (Kils, 1979a). Two groups of krill, each of 10 individuals, ranging from 0.554 $1.186 \mathrm{~g}$ in body weight, were used in this experiment. Members of the two groups were adapted to and incubated in the two different types of respirometer in the same way and individual oxygen uptake was measured at $0^{\circ} \mathrm{C}$ by the same method. 


\section{Effect of period of adaptation to respirometer}

In this experiment, twenty krill ranging from 0.523 to $0.963 \mathrm{~g}$ in body weight were used to study the effect of period of adaptation to respirometer $\sigma$ : oxygen consumption. The animals were divided into four groups, each of five animals, and allowed to adapt individually to the static respirometer for 1, 3,6 and 12 hours with running sea water. After this period water supply was cut off, the respirometers were sealed and the animals were allowed to take up oxygen for 3 hours at $0^{\circ} \mathrm{C}$.

\section{Effect of temperature on routine respiration rate}

To study the effect of temperature on routine respiration rate, four groups of krill in a range of body weight from 0.400 to $1.170 \mathrm{~g}$ were employed. The krill were acclimated to $0,1,2,3$ and $4^{\circ} \mathrm{C}$ over a period of $48 \mathrm{~h}$ and individual routine respiratory rate of each group was measured with static respirometer at its respective acclimated temperature. At least 16 krill were used at each temperature, a total of 81 animals in all. Incubation period was 3 hours. Temperatures higher than $0^{\circ} \mathrm{C}$ were maintained by heaters and thermostats.

\section{Effect of short-termed starvation}

To study the effect of short-termed starvation on routine respiration rate krill ranging from 0.547 to $0.862 \mathrm{~g}$ in body weight were maintained without food in 1000 liters aquarium over a period of 7 days with current water filtered through a $2 \mu \mathrm{m}$ filter. Every other day 5 krill were randomly sampled and their individual routine respiration rate were measured in static respirometer at the acclimated temperature of $0^{\circ} \mathrm{C}$. Incubation period was 3 hours.

\section{Effect of body weight}

A total of $161 \mathrm{krill}$ ranging from 0.23 to $1.49 \mathrm{~g}$ in body weight was used to study the effect of body weight on oxygen consumption. Oxygen consumption was measured at $0 \pm 0.5^{\circ} \mathrm{C}$ in sealed static respirometers. Krill were individually adapted to the respirometer for 3 hours then incubated for 3 hours based upon results of experiments on the effect of period of adaptation and type of respirometer. All measurements were made during daytime and no krill was used twice. Dissolved oxygen was measured by Winkler method modified for small samples of water by Fox \& Wingfield (1938). After each experiment, wet weight was taken, the animal was then sacrificed and oven dried to constant weight in $85^{\circ} \mathrm{C}$. The relationship between wet and dry weight were established and used to calculate dry weight which was accidentally lost in some animals.

\section{Results}

\section{Effect of period of adaptation to respirometer}

Results of experiments on the effect of period of adaptation to respirometer are shown in Figure 1. Each point in the figure represents average of 5 measurements and vertical bars are standard deviations. Although consumption after different periods of adaptation was not significant, except the consumption after three and twelve hours (Tukey HSD test, $p=0.0095$ ), the consumption after three hours of adaptation is the lowest in mean and smallest in standard derivation. The consumption after twelve hours is the highest in mean and largest in standard derivation.

\section{Type of respirometer}

Results of experiments to study the effect of different types of respirometer on oxygen consumption of krill are shown in Table 1. Average oxygen consumption of krill in respirometer with stirring device is almost three times higher than that of krill in respirometer without the device. Standard deviation of the former is also higher than that of the latter.

\section{Effect of starvation}

Results of experiments to study the effect of starvation are shown in Table 2. No significant difference in whole animal consumption was detected (ANOVA, $\mathrm{p}=0.0594$ ).

\section{Effect of temperature}

The effect of temperature on metabolic rate is best illustrated by plot of means as shown in the Figure 2. From 0 to $1^{\circ} \mathrm{C}$ the temperature exerts no effect on metabolism. From 1 to $4^{\circ} \mathrm{C}$ the metabolism increases rapidly in function of temperature. The metabolic rate, at $2^{\circ} \mathrm{C}$ is $682.10 \pm 121.87 \mu \mathrm{OO}_{2} \mathrm{~g}$ (dry $w)^{-1} h^{-1}$, and significantly different from $511 \pm 36.31$ at $0^{\circ} \mathrm{C}$ and $836.12 \pm 109.05$ at $4^{\circ} \mathrm{C}$ (Tukey HSD multiple tests, $p=0.0001$ and $p=0.0002$ respectively). The increase becomes less steep at the higher temperatures (2 to $4^{\circ} \mathrm{C}$ ), which is in accord with the frequently observed phenomenon of a reduced $Q_{10}$ with temperature increase. Values of $\mathrm{Q}_{10}$ for all possible intervals of temperature are in Table 3. 


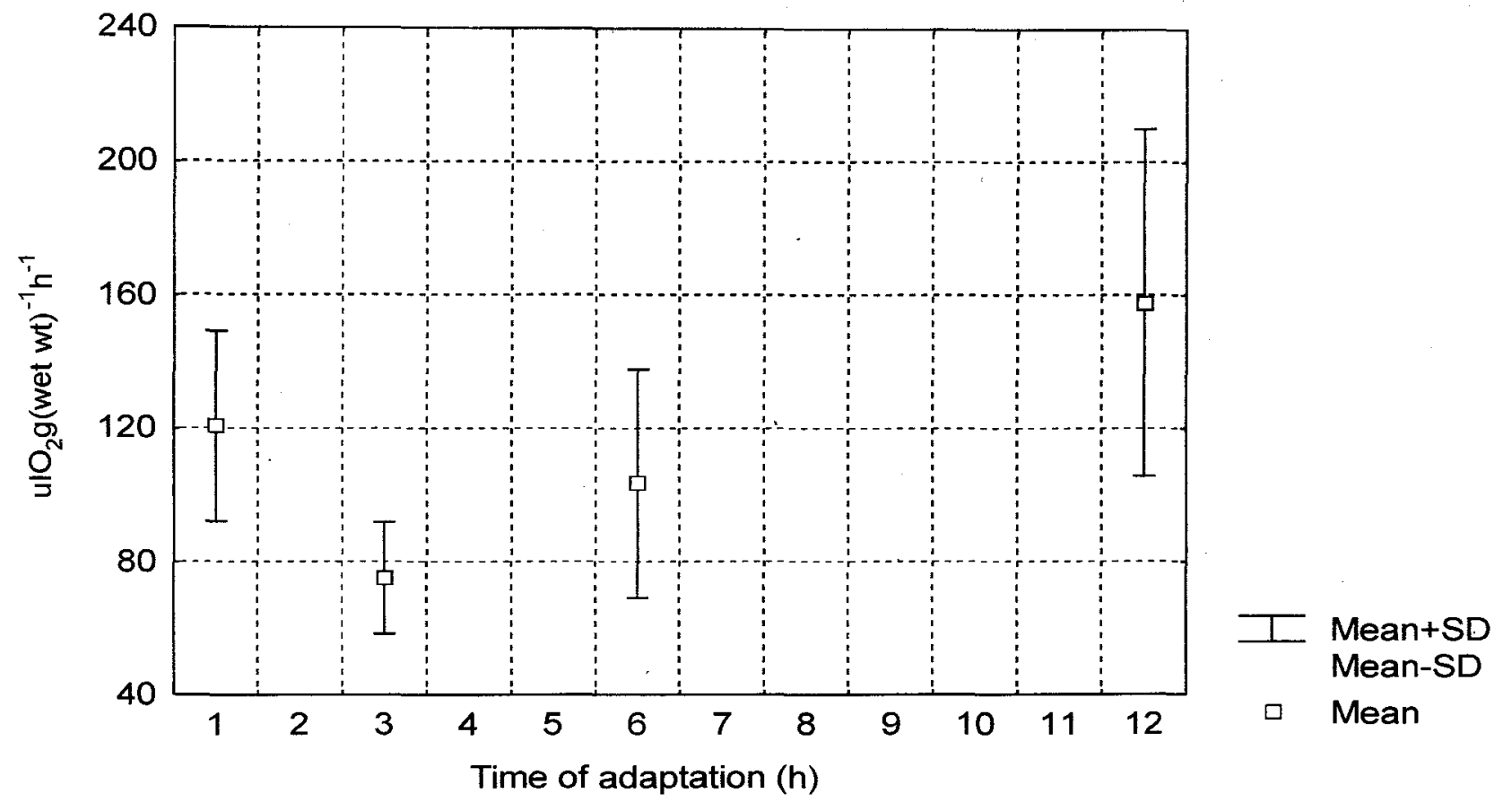

Fig. 1. Variation of metabolic rate, $\mu \mathrm{lO}_{2} \mathrm{~g}(\text { wet } w t)^{-1} h^{-1}$, in function of time of adaptation to respirometer.

Table 1. Comparison of metabolic rate, $\mu \mathrm{OO} 2 \mathrm{~g}(\text { wet } w t)^{-1} \mathrm{~h}^{-1}$, of krill measured in different types of respirometer.

\begin{tabular}{|l|c|c|}
\cline { 2 - 3 } \multicolumn{1}{c|}{} & Without Steering Device & With Steering Device \\
\hline No of krill & 10 & 10 \\
Temperature $\left({ }^{\circ} \mathrm{C}\right)$ & 0 & 0 \\
Mean wet weight $(\mathrm{g})$ & 0.874 & 0.872 \\
Standard deviation & 0.128 & 0.248 \\
Mean metabolic rate & 66.162 & 137.514 \\
Standard deviation & 2.147 & 2.029 \\
\hline
\end{tabular}

Table 2. Effect of starvation on metabolic rate, $\mu \mathrm{lO} 2 \mathrm{~g}(\text { wet } w t)^{-1} h^{-1}$, of krill.

\begin{tabular}{|l|r|r|r|r|}
\cline { 2 - 5 } \multicolumn{1}{c|}{} & \multicolumn{4}{c|}{ Starvation } \\
\cline { 2 - 5 } \multicolumn{1}{c|}{} & 1 st day & 3rd day & 5th day & 7th day \\
\hline No. of krill & & & & 5 \\
Mean wet weight (g) & 5 & 5 & 5 & 0.730 \\
Standard deviation & 0.766 & 0.643 & 0.744 & 0.086 \\
Temperature $\left({ }^{\circ} \mathrm{C}\right)$ & 0.038 & 0.071 & 0.101 & 1 \\
Mean metabolic rate & 1.5 & 1.5 & 1.5 & 128.636 \\
Standard deviation & 129.491 & 91.259 & 131.348 & 16.026 \\
\hline
\end{tabular}




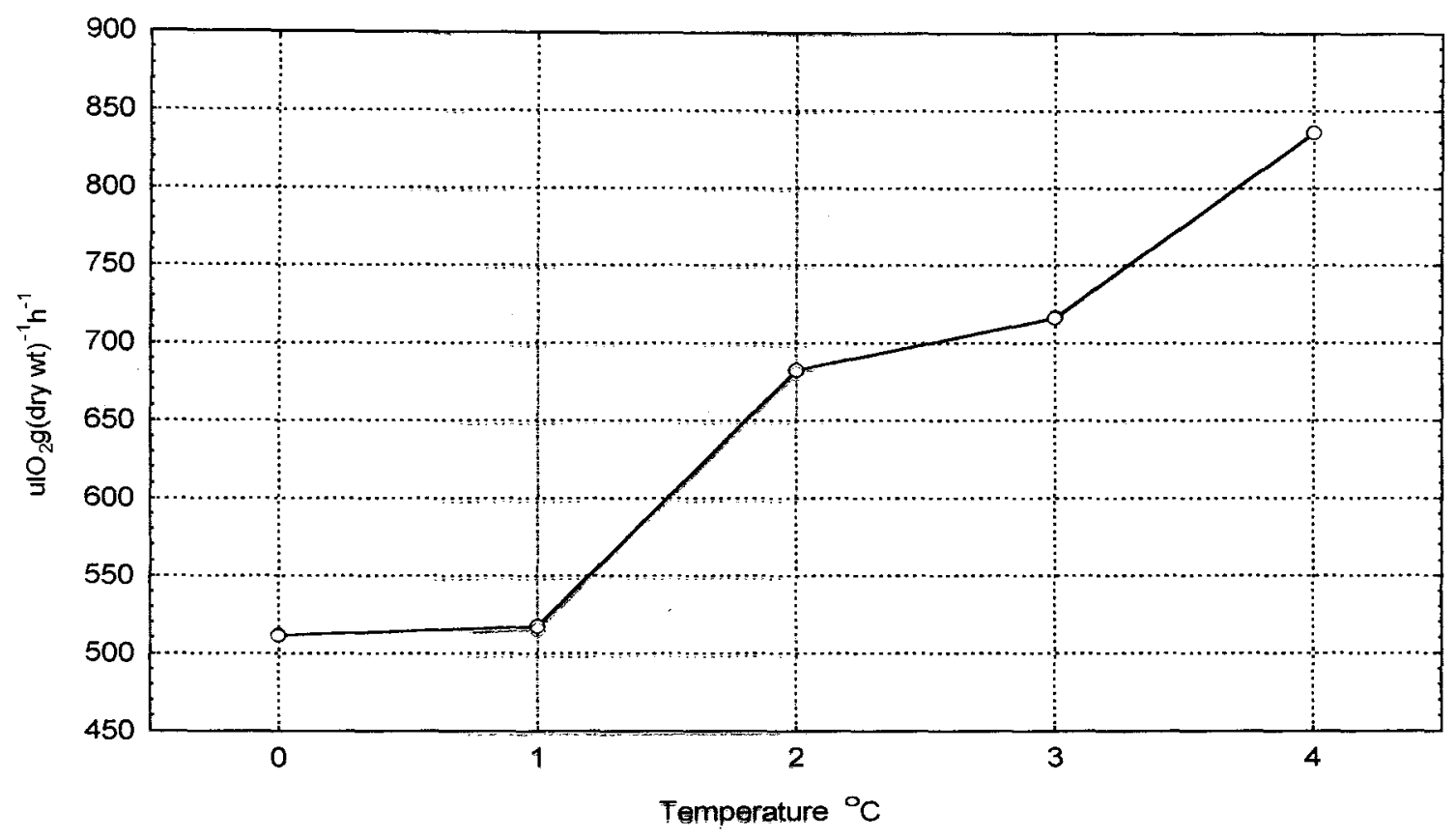

Fig. 2. Variation of mean metabolic rate, $\mu 1 \mathrm{O}_{2} \mathrm{~g}(\mathrm{dry} w \mathrm{t})^{-1} \mathrm{~h}^{-1}$, in function of temperature.

Table 3. Values of $\mathrm{Q}_{10}$ for all possible intervals of temperature.

\begin{tabular}{|cc|c|c|c|c|}
\hline To & From & $0^{\circ} \mathrm{C}$ & $1^{\circ} \mathrm{C}$ & $2^{\circ} \mathrm{C}$ & $3^{\circ} \mathrm{C}$ \\
\hline $1^{\circ} \mathrm{C}$ & 0.94 & & & \\
$2^{\circ} \mathrm{C}$ & 4.04 & 17.38 & $\ldots$ & \\
$3^{\circ} \mathrm{C}$ & 2.87 & 5.01 & 1.45 & \\
$4^{\circ} \mathrm{C}$ & 3.40 & 5.21 & 2.85 & 5.64 \\
\hline
\end{tabular}

\section{Effect of body size on oxygen consumption}

Figure 3 illustrates the effect of body weight upon oxygen consumption of krill at $0^{\circ} \mathrm{C}$ in a logarithmic grid. There was a general increase in oxygen consumption with increasing body wet weight. The equation between consumption and wet weight is given by $\mathrm{Q}_{\mathrm{O} 2}=\mathrm{aW}^{0.987}$ or $\log \mathrm{Q}_{\mathrm{O} 2}=$ $2.061+0.987 \times \log W$ with $r=0.86$. The slope of the regression line $b=0.987$ is less than unity, indicating that oxygen consumption per unit weight is greater for the smaller than for the larger krill. Average metabolic rate of $164 \mathrm{krill}$ is $733.24 \pm 320 \mu \mathrm{OO}_{2} \mathrm{~g}(\mathrm{dry}$ $w t)^{-1} h^{-1}$. The metabolic rate is of $1129.67 \pm 328.96$ $\mu \mathrm{lO}_{2} \mathrm{~g}$ (dry $\left.\mathrm{wt}\right)^{-1} \mathrm{~h}^{-1}$ for small krill (13-19 $\mathrm{mg}$ dry weight) and $636.16 \pm 140.36 \mu 1 \mathrm{O}_{2} \mathrm{~g}(\mathrm{dry} \mathrm{wt})^{-1} \mathrm{~h}^{-1}$ for larger animals (160-169 mg dry weight) (Table 4). 


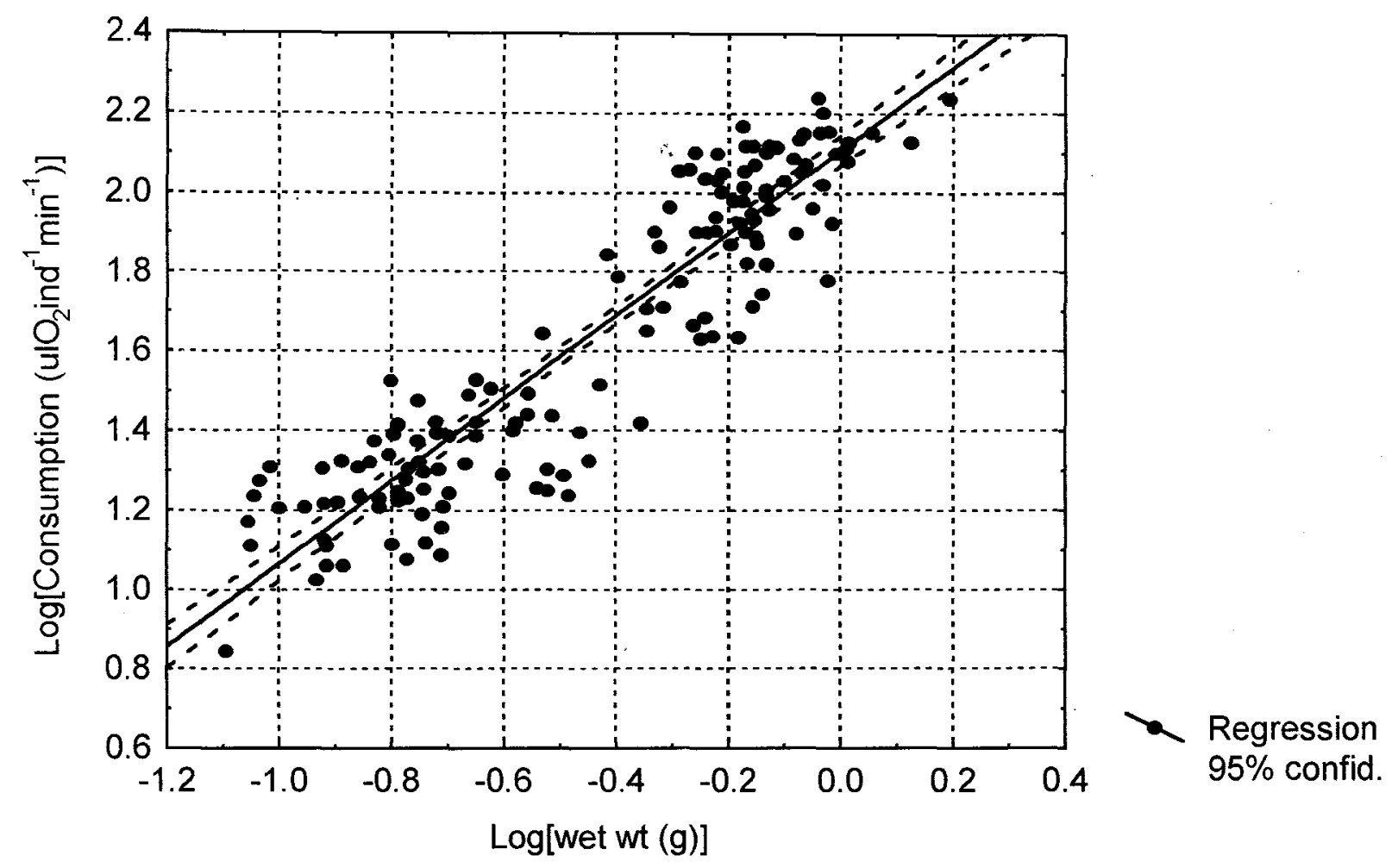

Fig.3. Variation of whole animal oxygen consumption in function of body weight.

Table 4. Mean metabolic rate, $\mu \mathrm{JO}_{2} \mathrm{~g}(\mathrm{dry} w \mathrm{w})^{-1} \mathrm{~h}^{-1}$. of krill of different dry weight. at $0^{\circ} \mathrm{C}$.

\begin{tabular}{|c|c|c|c|}
\hline Dry weight $(\mathrm{mg})$ & Number of & \multicolumn{2}{|c|}{ Metabolic rate $\mu \mathrm{IO}_{2} \mathrm{~g}\left(\mathrm{dry} w \mathrm{wt}^{-1} \mathrm{~h}^{-1}\right.$} \\
\cline { 3 - 4 } Class & $\mathrm{krill}$ & Mean & Standard deviation \\
\hline $13-19$ & 9 & 1129.67 & 328.96 \\
$20-29$ & 17 & 723.99 & 228.33 \\
$30-39$ & 18 & 546.87 & 201.78 \\
$40-49$ & 22 & 523.12 & 224.95 \\
$50-59$ & 6 & 485.36 & 217.21 \\
$60-69$ & 13 & 893.55 & 609.30 \\
$70-79$ & 3 & 931.00 & 371.60 \\
$80-89$ & 5 & 788.86 & 267.99 \\
$90-99$ & 10 & 862.98 & 281.77 \\
$100-119$ & 16 & 880.69 & 232.57 \\
$120-129$ & 16 & 715.33 & 259.75 \\
$130-139$ & 8 & 882.63 & 239.80 \\
$140-149$ & 5 & 612.17 & 168.72 \\
$150-159$ & 14 & 685.57 & 140.36 \\
$160-169$ & 2 & 636.16 & 2.21 \\
\hline All Classes & 164 & 733.24 & 320.00 \\
\hline
\end{tabular}




\section{Discussion}

\section{Effect of sampling and handling}

Krill used in this study are considered to be in a perfect physical condition because they were captured one by one with small aquarium hand-net and maintained in a large container (about 100 individuals $/ 1000$ liters) with running sea water pumped directly from where they were captured. Temperature, salinity and food supply may, therefore, be considered as normal. The stress caused by sampling must also be less than that of those captured by bongo-net, RTM-8, large commercial pelagic trawl or Isaacs-Kidd midwater trawl used by other authors (Kils, 1979b; Opalinski, 1991; Klekowski et al., 1991). Mortality during at least two weeks in captivity was close to zero. This may be attributed to the perfect physical conditions of the animals. With three domestic electric lamps of $150 \mathrm{~W}$ each it was possible to induce krill to gather in near shore where water depth is less than one meter. At the latitude of the Brazilian Antarctic Station $\left(62^{\circ} 05^{\prime} \mathrm{S}\right)$ the best time to catch kriil by this method is from about 1:00 to 2:00 a.m. of late February without interference of other light sources such as the moon or a ship. Using this method one frequently can catch 50-100 krill per fishing. The record established was about $5 \mathrm{~kg}$ of krill caught by four persons during about one hour of fishing.

As reported above type of the respirometer and time to recover from the stress of being placed in the respirometer may affect the oxygen consumption. Polar fishes (Holeton, 1974, 1983) and isopods (Luxmoore, 1981) may take $24-48 \mathrm{~h}$ to recover from the stress of handling. Our data suggested, however, that in the case of krill, prolonged confinement may perhaps cause another kind of stress which may severely affect its oxygen consumption. High metabolic rate after one hour of adaptation may be due to the effect of handling. High metabolic rates after six and 12 hours may be due to stress of being confined for a long period of time. Krill is a pelagic organism and must continuously swim to maintain in the water column. Prolonged confinement in a sealed respirometer with about $120 \mathrm{ml}$ of water may alters their physiological state. In our experiment all krill confined for 12 hours turned red and laid down at the bottom of the respirometer with vigorous movements of its pleopods. These movements may be one of the factors which rise the oxygen consumption of this group as showed in our results. To avoid this kind of problem, Kils (1979b) measured oxygen consumption of krill in gas tight chambers of 631 in which experimental animals were allowed with fairly free swimming and free orientation space.
Another experimental variable which affected oxygen consumption is the type of the respirometer. In our experiment oxygen consumption of krill in respirometer with stirring device is significantly higher than that of krill in respirometer without this device. High consumption in respirometer with stirring device may be due to stress caused by the stirring device or movements of the experimental animal induced by the flow which is created by stirring. In some aquatic invertebrates the flow of water around them has been shown to increase their metabolic rate (Patterson, 1992). They are dependent on diffusion through a boundary layer, the very thin layer of water directly surrounding a organism, for uptake of metabolically important compounds such as oxygen and the boundary layer getting thinner as the speed of water flow increases. Luxmoore (1984) compared oxygen consumption of Antarctic isopods using interrupted-flow technique and simple sealedchamber method and reported that the former gave a significantly lower oxygen consumption than the latter. Aarset \& Torres (1989), on the other hand, observed that the metabolic rate fluctuates within a fairly wide range irrespective of the measurement method used.

\section{Effect of starvation}

The effect of starvation on respiratory metabolism of krill has been studied by several authors. Hirche (1983) studied the effect of starvation on respiration of krill over 7 days period and observed large variations during the course of the experiment but no clear trends were revealed. Opalinski (1991) followed oxygen consumption of krill during 5 days (58 hours) in an environment with greatly limited amount of food and reported that the metabolic rate remained virtually unchanged. To carry out the experiment, the author used sea water filtered through a net with mesh size of $55 \mu \mathrm{m}$. Krill feed predominantly on phytoplankton (that may be retained by $55 \mu \mathrm{m})$ but they may feed on nanoplankton (organisms smaller than $20 \mu \mathrm{m}$ ) which may constitute $70 \%$ of the phytoplankton standing stock in Antarctic waters (von Bröckel, 1981). In laboratory krill was shown to filter most efficiently particles of $30 \mu \mathrm{m}$ in diameter (Morris, 1984) but they are able to remove particles as small as $6 \mu \mathrm{m}$ (Boyd et al., 1984). In our experiments variation of oxygen consumption of krill maintained during 7 days in the water filtered through filter of $2 \mu \mathrm{m}$ was not significant. This may be considered as a compensation of krill to the spatial and temporal patchiness of food in the Southern Ocean. In laboratory, krill may survive for more than 200 days without food. During long-term starvation, both 
ammonia and oxygen uptake increase and krill is believed to use its own tissues to survive as its body shrinks (Ikeda \& Mitchell, 1982a,b).

\section{Effect of temperature}

The environmental factor which probably has the greatest effect on metabolic rate in exothermic animals is temperature. Experiments were, therefore, conducted to measure respiration at a variety of temperatures found in the normal range of distribution of krill. The krill is known to have a broad distribution south of the Polar Front. This wide horizontal distribution exposes krill to temperatures ranging from $-1.8^{\circ} \mathrm{C}$ in the vicinity of the Antarctic continent to about $4^{\circ} \mathrm{C}$ in the waters adjacent to the Front. After being released and fertilized in the surface waters the eggs of krill sink rapidly and hatch at $800 \mathrm{~m}-2500 \mathrm{~m}$ (Marschall, 1983; Quetin \& Ross, 1984; Hempel, 1985); larvae then ascend during development, arriving in the surface layers at metamorphosis to the first feeding stage. During their developmental descent and ascent the embryos and larvae may encounter a range of temperature from -1.8 to $2.5^{\circ} \mathrm{C}$, or higher. The temperature of $4^{\circ} \mathrm{C}$ is considered to be the upper lethal limit for this species by various authors (McWhinnie \& Marciniak, 1964; Aarset \& Torres, 1989) although experimentally they have been submitted to much higher temperatures. At $10^{\circ} \mathrm{C}$ the animals survived 2 days, with acclimation rate of $2.5^{\circ} \mathrm{C}$ per day (Opalinski, 1991).

McWhinnie \& Marciniak (1964) examined the acute effect of temperature on the metabolic rate of krill and found that from 0 to $5^{\circ} \mathrm{C}$ there is a slight increase in weight-specific oxygen consumption. The consumption showed no increase above the $5^{\circ} \mathrm{C}$ level when measured at 10 and $15^{\circ} \mathrm{C}$. The response to temperature seemed to depend on the size of krill. Segawa et al. (1979) reported that for small krill (0.13-0.19 $\mathrm{g}$ wet weight) the rate of oxygen consumption varied little from -1.5 to $2^{\circ} \mathrm{C}$. From 2 to $5^{\circ} \mathrm{C}$ the rate increased rapidly. For large krill (0.86-1.7 $\mathrm{g}$ wet weight) the rate increased significantly from -1.5 to $0^{\circ} \mathrm{C}$, slowdown from 0 to $3.5^{\circ} \mathrm{C}$, and continued to increase from 3.5 to $5^{\circ} \mathrm{C}$. Quetin \& Ross (1989) studied oxygen consumption rates for larvae of krill from -1.0 and $2{ }^{\circ} \mathrm{C}$ and observed that the effect of temperature on oxygen consumption was not linear and that oxygen consumption rates for the larvae at 0 and $2^{\circ} \mathrm{C}$, the usual temperatures of surface water, are essentially temperature independent and much higher than those at $-1{ }^{\circ} \mathrm{C}$. The independence of temperature of metabolic rate of krill within the range of temperatures characteristic of the natural environment (from -1.8 to $+2.5^{\circ} \mathrm{C}$ ) was reported also for adult krill (Opalinski, 1991). A further increase of temperature leads to an abrupt rise of the metabolic rate. The author considered the lack of metabolic reaction to temperature changes within the range of $2^{\circ} \mathrm{C}$ as an expression of optimization of the metabolic processes since during its 24 -h vertical migrations from the surface to $70-150 \mathrm{~m}$ depth krill comes in contact with water mass differing in temperature by $0.8-1.2^{\circ} \mathrm{C}$. The pattern of response of metabolism of krill to temperatures in our experiments is somewhat different. The Figure 2 shows a zone of independence $\left(0\right.$ to $1^{\circ} \mathrm{C}$ with $\mathrm{Q}_{10}$ near to unity) which is narrower than those observed by Opalinski (1991) for adult and Quetin \& Ross (1989) for embryo and larvae of krill. From 1 to $2^{\circ} \mathrm{C}$ the metabolic rate increases rapidly, and from 2 to $4^{\circ} \mathrm{C}$ it continues to increase but apparently less. Different patterns obtained in different works may be due to factors related to the animals and to methods employed. Nevertheless, the similarity of the general trend indicates the existence of a range of temperature in which metabolic rates remain fairly constant. Experiments at temperatures less than $0^{\circ} \mathrm{C}$ were not carried out in our study.

\section{Oxygen drop}

One of the disadvantages of sealed respirometer is that the oxygen concentration of water in the respirometer decreases continuously as long as the animal is kept inside and it was well known that environmental level of oxygen affects metabolism of organisms. The final concentration of oxygen in our experiment has never dropped to below $70 \%$ the level of natural water. Opalinski (1991) studied the effect of a gradual decrease of the water oxygen content from 100 to $37 \%$ of saturation and found that a decrease in water oxygen content to $78 \%$ of saturation virtually exerts no perceptible effect on metabolic rate of krill. A drop to $68 \%$ of saturation causes a decrease in the metabolic rate. This level persists during a further drop in oxygen content to $37 \%$ of saturation. The first individual died when the contents drops to $44 \%$ of saturation. Kils (1979b) investigated the relationship between oxygen tension and oxygen uptake of free swimming krill and demonstrated that adult krill caught in summer died at $85 \%$ of saturation and that critical oxygen concentration is about $90-85 \%$. At this level luminescence ceases, respiration cannot be compensated and the swimming behavior changes. Clarke and Morris (1983) reported a relatively high tolerance of hypoxia in krill. Both filtration rate and swimming activity remained normal as oxygen saturation was lowered down to about $39 \%$. 


\section{Body size}

The effect of body weight on oxygen consumption of krill is similar to that found for other species. In general, oxygen consumption increases linearly with body size when the two variables are plotted on double log coordinates. In our experiment the slope of the regression line is $b=0.987$ and is comparable to $0.965 ; 0.950$ and 0.969 respectively reported by Chekunova \& Rynkova (1974), RakusaSuszczewski \& Opalinski (1978) and Ikeda \& Mitchell (1982a). The value of $b$ according to Opalinski (1991) may vary from 0.52 to 1.16 and is different between male and female with different stages of maturation (Klekowski et al., 1991). Our data on metabolic rate (Table 4) are within the range of comparable data in the literature and confirm their high variablity as stated by other authors (see Clark \& Morris, 1983; Miller \& Hampton, 1989 and Opalinski, 1991 for review). Routine metabolism of Euphausia superba is known to vary in function of molting stages, activity, season and others environmental factors (Rakusa-Suszczewski \& Opalinski, 1978; Opalinski, 1991; Torres et al., 1994; Phan et al., unpublished data).

The experiments provided us with useful data about the basic metabolic requirement of krill and helpful information to understand the variability of results previously published by various authors.

\section{Acknowledgments}

We thank CNPq-PROANTAR, IOUSP for financial, SECIRM, and Brazilian Antarctic Station "Comandante Ferraz" for logistical supports. Part of this work was developed under the auspices of Brazilian-Germany Cooperation (MCTCNPq/IOUSP/BAH, ANT-4).

\section{References}

Aarset, A. V. \& Torres, T. 1989. Cold resistance and metabolic responses to salinity variations in the Amphipod Eusirus antarcticus and the krill Euphausia superba. Polar Biol., 9:491-497.

Boyd, C. M.; Heyraud, M. \& Boyd, C. N. 1984. Feeding of the Antarctic krill Euphausia superba. J. Crust. Biol., 4 (Spec. nº 1):123-141.
Chekunova, V. I. \& Rynkova, T. I. 1974. Energy requirements of the Antarctic crustacean Euphausia superba Dana. Oceanology, 14:434440.

Clarke, A. \& Morris, D. J. 1983. Towards an energy budget for krill. The physiology and biochemistry of Euphausia superba Dana. Polar Biol., 2:69-86.

Fox, H. M. and Wingfield, C. A. 1938. A portable apparatus for the determination of oxygen dissolved in a small volume of water. J. expl. Biol., 15:437-445.

Fry, F. E. J. 1971. The effect of environmental factors on the physiology of fish. In: Hoar, W. S. and Randall, D. J., eds. Fish Physiology. New York and London, Academic Press. p. 1-98.

Hempel, I. 1985. Vertical distribution of larvae of Antarctic krill, Euphausia superba . In: Siegfried, W. R.; Condy, P. R. \& Law, R. M., eds. Antarctic nutrient cycles and food webs. Berlin, SpringerVerlag. p. 308-310.

Hirche, H. J. 1983. Excretion and respiration of the Antarctic krill Euphausia superba. Polar Biol., 1:205-209.

Holeton, G. F. 1974. Metabolic cold adaptation of polar fish: Fact or artifact? Physiol Zoöl., 47:137152.

Holeton, G. F. 1983. Respiration of arctic char (Salvelinus alpinus) from a high arctic lake. J. Fish. Res. Bd Can., 30:717-723.

Ikeda, T. \& Mitchell, A. W. 1982a. Oxygen uptake, ammonia excretion and phosphate excretion by krill and other Antarctic zooplankton in relation to their body size and chemical composition. Mar. Biol., 71:283-298.

Ikeda, T. \& Mitchell, A. W. 1982b. Body shrinkage as a possible over-wintering mechanism of the Antartic krill, Euphausia superba Dana. J. expl. mar. Biol. Ecol., 62:143-151.

Kils, U. 1979a. Preliminary data on volume, density and cross section area of Antarctic krill Euphausia superba. Meeresforsch., 27:207-209.

Kils, U. 1979b. Performance of Antarctic krill Euphausia superba at different levels of oxygen saturation. Meeresforsch., 27:35-48. 
Klekowski, R. Z.; Opalinski, K. W. \& Maklygin, L. G. 1991. Respiratory metabolism of Euphausia superba: the effect of gonadial development. In: Klekowski, R. Z. \& Opalinski, K. W., eds First Polish-Soviet Antartic Symposium "ARCTOWSKI'85". Poland, Polish Academy of Sciences, p. 109-117.

Luxmoore, R. A. 1981. The ecology of Antarctic serolid isopods. PhD Thesis. Council for National Academic Awards. 231p.

Luxmoore, R. A. 1984. A comparison of the respiration rate of some Antarctic isopods with species from lower latitudes. Br. Antarct. Surv. Bull., 62:53-65.

Marschall, H. P. 1983. Sinking speed, density and size of euphausiid eggs. Meeresforsh., 30:1-9.

McWhinnie, M. A. \& Marciniak, P. 1964. Temperature responses and tissue respiration in Antarctic crustacea with particular reference to krill Euphausia superba. In: Lee, M. O. ed. Biology of the Antarctic sea. Antarctic. Res. Ser., 4:63-72.

Miller, D. G. M. \& Hampton, I. 1989. Biology and ecology of the Antarctic krill (Euphausia superba Dana): A review. BIOMASS Scientific Series $n^{\circ}$ 9. 166p.

Morris, D. J. 1984. Filtration rates in Euphausia superba: under or over estimates? J. Crust. Biol., 4 (Spec. $\mathrm{N}^{\circ} 1$ ): 185-197.

Opalinski, W. K. 1991. Respiratory metabolism and metabolic adaptations of Antarctic krill Euphausia superba. Pol. Archs Hydrobiol., 38:183-263.

Patterson, M. R. 1992. A mass transfer explanation of metabolic scaling relations in some aquatic invertebrate and algae. Science, 255:1421-1423.

Quetin, L. B. \& Ross, R. M. 1984. Depth distribution of developing Euphausia superba embryos, predicted from sinking rates. Mar. Biol., 79:4753.

Quetin, L. B. \& Ross, R. M. 1989. Effects of oxygen, temperature and age on the metabolic rate of the embryos and early larval stages of the Antarctic krill Euphausia superba Dana. J. expl. mar. Biol. Ecol., 125:43-62.
Rakusa-Suszczewski, S. \& Opalinski, K. W. 1978. Oxygen consumption in Euphausia superba. Pol. Archs Hydrobiol., 25:633-641.

Segawa, S.; Kato, M. \& Marano, M. 1979. Oxygen consumption of the Antarctic krill Euphausia superba. Trans. Tokyo Univ. Fish., 5:177-187.

Torres, J. J.; Aarset, A. V.; Donnelly, J.; Hopkins, T. L.; Lancraft, T. M. \& Ainley, D.G. 1994. Metabolism of Antarctic micronektonic Crustacea as a function of depth of occurrence and season. Mar. Ecol.-Prog. Ser., 113:207-219.

von Bröckel, K. 1981. The importance of nanoplankton within the pelagic Antarctic ecosystem. Kieler Meeresforsch., 5:61-67. 